Copyright (C) 2018 by the Kalmyk Scientific Center of the Russian Academy of Sciences

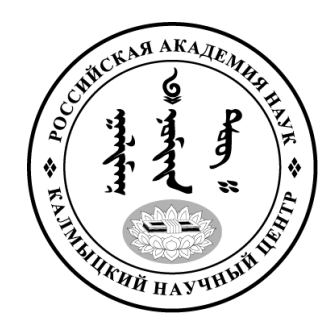

Published in the Russian Federation

Oriental Studies (Previous Name: Bulletin of the Kalmyk Institute for

Humanities of the Russian Academy of Sciences)

Has been issued as a journal since 2008

ISSN: 2619-0990; E-ISSN: 2619-1008

Vol. 39, Is. 5, pp. 174-186, 2018

DOI 10.22162/2619-0990-2018-39-5-174-186

Journal homepage: https://kigiran.elpub.ru

УДК 398.22

\title{
Синоптический анализ прологов «Джангара» (Багацохуровский цикл 1857-1862 гг.)
}

\author{
Байрта Барбаевна Манджиева ${ }^{1}$
}

${ }^{1}$ кандидат филологических наук, ведущий научный сотрудник, отдел монгольской филологии, Калмыцкий научный центр РАН (358000, Россия, г. Элиста, ул. им. И. К. Илишкина, д. 8). ORCID: 0000-0002-5644-3340.E-mail: mbbairta@yandex.ru

\begin{abstract}
Аннотация
Цель. Статья посвящена изучению прологов Багацохуровского цикла «Джангара» с целью выявления устойчивости эпического текста, определения основы и принципов сложения экспозиционной части эпоса.

Memodbl. При анализе записей двух прологов Багацохуровского цикла применяется метод полного синоптического сопоставления текстов, представленный В. М. Гацаком для эпоса.

Результатыл. В результате синоптического сопоставления прологов песен-поэм «Дуут богд Жаңһр догшн Хар Кинесиг дөрәцүлгсн бөлг» ('О том, как славный богдо Джангар свирепого Хара Кинеса покорил’) и «Догшн Замбл хаана һалзу долан бодңгиг Аср Улан Хоңһр Күнд Һарта Савр хойр дөрәцүлгсн бөлг» ('О победе Улан Хонгора Могучего и Тяжелорукого Савара над семью неукротимыми вепрями [-богатырями] свирепого Замбал-хана’) Багацохуровского цикла образовалось 1383 строчных позиций. Синоптическая «развертка по вертикали» и сопоставление паритетных стихов выявили 153 стиха, совпадающих текстуально и позиционно. Для 105 стихов соответствия нашлись не рядом, а в других местах. В 112 случаях стихи хотя и различаются в той или иной степени, но все же совпадают между собой, варьируя одну и ту же основу. Совпадающих текстуально и позиционно, но с долей синонимии в деталях нами обнаружено 205 стихов. Таким образом, в результате синоптического сопоставления двух записей пролога Багацохуровского цикла 575 строчных позиций целиком и частично тождественны, и мы можем утверждать, что джангарчи, зная принципы сложения эпоса, строит свое повествование по определенной схеме: 1) описание страны; 2) описание сооружения дворца; 3) описание Джангара, его оружия и коня; 4) описание местоположения персонажей; 5) подчинение богатыря Савара; 6) пир во дворце Джангара; 7) восхваление страны.

Bblвodbl. Рассмотрение прологов подтверждает положение о том, что фольклорный текст в процессе многократного устного исполнения всегда варьируется. Во время исполнения сказитель использует готовые темы, общие места и поэтические формулы. Пролог, являясь важным композиционным слагаемым эпоса, способствует более полному восприятию эпической поэмы, героических подвигов богатырей, акцентирует внимание на величии самих событий, происходящих в Бумбайской стране, чем обширнее пролог, тем величественнее эпическое государство; присутствие пролога свидетельствует об устойчивости и формировании эпоса «Джангар в большом историческом времени.

Ключевые слова: эпос, традиция, пролог, рукопись, синоптический анализ, текст, сказитель, вариативность
\end{abstract}


Калмыцкий героический эпос «Джангар» предваряется вступительной частью, которую джангарчи называет оршл ('пролог'). В фольклористике экспозиционная часть эпоса остается малоизученной, обратились мы к данной проблеме в связи с изучением «Джангара». Вопросы изучения пролога калмыцкого эпоса «Джангар» освещены в трудах А. Ш. Кичикова [Кичиков 1992], Э. Б. Овалова [Овалов 1977], Б. Б. Манджиевой [Манджиева 2003; 2004а; 2004б; 2014; 2015], Д. В. Убушиевой [Убушиева 2009; 2012; 2016а; 2016б]. Предметом настоящего исследования является синоптический анализ прологов Багацохуровского цикла «Джангара» с целью выявления устойчивости эпического текста, определения основы и принципов сложения экспозиционной части эпоса.

Одним из первых, кто заметил повторяющуюся вступительную часть эпоса «Джангар», является Номто Очиров (1886-1960), записавший в 1908 г. полный эпический репертуар выдающегося рапсода Ээлян Овла. Во время записи Номто Очиров заметил, что джангарчи каждый раз начинает песнь одинаково, поэтому собиратель после записи четырех песен стал пропускать начало песни, сделав отсылку «Начало смотрите в первых двух листах». Таким образом, Номто Очировым были записаны прологи к следующим песням: «О том, как Мингъян пригнал табун Алтан Тюрег хана» - пролог составляет 250 стихотворных строк; «О женитьбе Хонгора» - 280 стихотворных строк; «О пленении Хонгором Аля Монхули» -278 стихотворных строк, и в неполной 11-й песне (Песнь не имеет названия) - 193 строки. К сожалению, прологи к остальным песням не были зафиксированы.

В калмыцкой эпической традиции пролог является важной традиционной частью «Джангара», о чем свидетельствуют циклы и эпические репертуары:

1. Малодербетовский цикл (1862 г.), включающий три песни-поэмы;

2. Багацохуровский цикл (1857-1862 гг.) - 3 песни;

3. Малодербетовский эпический репертуар Ээлян Овлы из 10 песен;

4. Икицохуровский малый цикл джангарчи Давы Шавалиева из 4 песен;

5. Малодербетовский эпический репертуар сказителя Насанки Болдырова 1 песнь-поэма;
6. Донской эпический репертуар сказителя Бадмы Обушинова - 1 песньпоэма.

У каждого цикла имеется свой пролог.

Багацохуровский цикл «Джангара», так же как и Малодербетовский, относится к наиболее ранней фиксации XIX в. и представлен тремя песнями:

1. «Хар Кинесиг дөрәцүлгсн бөлг» ('O покорении Хара Кинеса'),

2. «Догшн Шар Маңһс хааг дөрәцүлгсн бөлг» ('О пленении свирепого Шара Мангаса-хана')

3. «Догшн Замбл хааг дөрәцүлгсн бөлг» ('О покорении свирепого Замбал-хана').

Эти три песни были зафиксированы в середине XIX в. разными собирателями, которые, к сожалению, не записали имя выдающегося джангарчи. Оригиналы рукописей этих песен хранятся в архивах СанктПетербурга под следующими шифрами: [Golstunsky Collection. 908 Incipit: Calm. C. 17, inv. No. 1770. Xyl. F 63. (1857), No. 2; HA РГО СПб. Оп. 1. Д. № 15].

Рукопись песни «О Замбал-хане» долгое время считалась утерянной. Оригинал этой песни был обнаружен только в 1979 г. аспирантом Института востоковедения АН СССР В. 3. Цереновым. Наряду с десятью песнями рапсода Ээлян Овла данная песнь была опубликована в двуязычном томе «Калмыцкий героический эпос «Джангар» [Джангар 1990].

В 1862 г. под руководством К. Ф. Голстунского были зафиксированы песни «Джангара» - «О Шара Гюргю» и «О Хара Кинесе», которые впоследствии в 1864 г. ученый издал на ойратской письменности («тодо бичиг» 'ясное письмо') [Jangar 1864]. После этой публикации эпические песни не раз публиковались в различных изданиях.

В 1940 г. С. А. Козин в своей книге «Джангариада. Героическая поэма калмыков. Введение в изучение памятника и перевод торгутской его версии» [Козин 1940] объединил песни Багацохуровского цикла и издал их переводы вместе с песнью «ШараГюргю», принадлежащей к Малодербетовскому циклу. «Не углубляясь в вопросы цикличности, „Племенной принадлежности“ эпических песен, ученый не обратил внимания на сходство двух экспозиций песен «О Хара Кинясе» и «Шара-мангус хане» (см. табл. 1). 
Таблица 1. Соотношение песен эпоса «Джангар»

\begin{tabular}{|c|l|c|l|}
\hline I. & Песнь о битвах Джангара с Черным князем & II. & $\begin{array}{l}\text { Песнь о победе богатырей Джангара } \\
\text { над семью богатырями Желто- } \\
\text { Мангусова хана }\end{array}$ \\
\hline 1. & Алтайская страна & 1. & Алтайская страна \\
\hline 2. & Золотой терем Джангара & 2. & Дворцы хана Джангара \\
\hline 3. & Джангар с дружиной & 3. & Джангар и его дружина \\
\hline 4. & Копье и конь Джангара & 4. & Супруга Джангара \\
\hline 5. & Стремянный, супруга и богатыри-сподвижники & 5. & Богатырь Алтан-Цэджи \\
\hline 6. & Богатырь Алтан-Цэджи (Золотая грудь) & 6. & Богатырь Улан-Хонгор \\
\hline 7. & Богатырь Улан-Хонгор, развеселый-хмельной & 7. & Богатырь Эргю-Гомбо \\
\hline 8. & $\begin{array}{l}\text { Богатырь Цусуни-Хара-Шорончи (Черно- } \\
\text { кровавый штык) }\end{array}$ & 8. & Богатырь Савар \\
\hline 9. & Богатырь Савар Тяжелорукий & 9. & Дверник Кей-Джилбанг \\
\hline 10. & Пир в Тереме Джангара & 10. & Пир во дворце Джангара \\
\hline
\end{tabular}

Отсюда исходит заключение С. А. Козина, что все песни его перевода составляют торгудскую версию» [Манджиева 2004а: 26-27]. Опровержимым доказательством данного С. А. Козиным заключения служит найденный в 1966 г. А. Ш. Кичиковым текст двух песен Малодербетовского цикла. С этого времени стало очевидным, что песнь «Шара-Гюргю» относится к репертуару неизвестного джангарчи Малодербетовской школы. Одним из весомых доказательств является повторяющийся во всех трех песнях-поэмах пролог цикла.

В Багацохуровском цикле также присутствует единый и объемный по содержанию пролог: объем всей песни «О Хара-Кинесе» 3015 стихотворных строк, ее вступительная часть - 911 стихотворных строк, объем песни «О Замбал-хане» составляет 1929 стихотворных строк, а пролог состоит из 859 стихотворных строк. Исключением является экспозиция второй песни - «О Шара Мангас хане», которая состоит из краткого описания в 35 стихотворных строк.

«В песнях Багацохуровского цикла воспеваются величие страны Бумбы, героические подвиги, совершаемые богатырями во славу хана Джангара и во имя мира на его благодатной земле» [Убушиева 2016а: 254].

Прологи двух песен «О том, как славный богдо Джангар свирепого Хара Кинеса покорил» и «О победе Улан Хонгора Могучего и Тяжелорукого Савара над семью неукротимыми вепрями [-богатырями] свирепого Замбал-хана» представляют слушателям величие эпической страны Бумбы, главного героя эпоса - богдо Джангара, его супругу Ага Герензел, главных богатырей - Алтан
Чеджи, Улан Хонгора, Гюмбе нойона, Боро Мангна, Савара. Пролог песни «О том, как Улан Хонгор Могучий пленил и доставил живым свирепого хана Шара Мангаса» дается в сокращенном варианте, но описания горы Орог Йондон Орза, горы Цаган, океана Шартаг, сооружения дворца, дерева Дамба Зули и восхваления страны, имеющиеся в тексте самой песни, аналогичны описаниям двух прологов цикла. Данный факт говорит о том, что все песни составляют единый цикл, кроме того, они были исполнены одним певцом-джангарчи, имя которого, к сожалению, осталось неизвестным.

При анализе записей двух прологов Багацохуровского цикла мы воспользовались методикой полного синоптического сопоставления текстов, разработанной В. М. Гацаком для эпоса [Гацак 1989: 65].

«1. Тексты даются параллельными колонками в согласованной „вертикальной развертке“, таким образом, чтобы идентичные или сходные стихи оказались на одном уровне - это сразу обнаруживает существующие совпадения;

2. Путем „растягивания“ текста по вертикали в его подаче создаются просветы, или паузы, когда в данном тексте нет стихов, которые заключаются в одной или в нескольких других сопоставляемых записях;

3. Все получающиеся строчные позиции нумеруются;

4. Там, где в данном тексте (или в данной стиховой позиции) нет стиха, имеющегося в другом тексте, ставится прочерк;

5. Если соответствующий стих имеется, но в другом месте, то вместо прочерка дается отсылка см. (когда стих тот же) или 
ср. (когда сходство неполное), с указанием номера позиции (два последних пункта важны тем, что выявляют неявные переклички и существенно дополняют фиксацию реального соотношения текстов);

6. При полном совпадении стиха в двух и более сопоставляемых записях стих располагается так, чтобы видна была его принадлежность соответствующим вариантам;

7. Когда в одном и том же стихе двух и более текстов различаются отдельные слова или их формы, это отражается при воспроизведении стиха» [Гацак 1989: 65].

Синоптическое сопоставление двух прологов Багацохуровского цикла калмыцкого героического эпоса «Джангар» демонстрирует соотношение вербальных и композиционных компонентов. Приводимые текстологические таблицы являются «не просто иллюстрацией к доказываемым тезисам, а самое доказательство» [Гацак 1989: 66]. Более того, синоптический анализ этих записей является доказательством того, что обнаруженная в архиве Русского Географического Общества в 1979 г. аспирантом Института востоковедения АН СССР В. 3. Цереновым эпическая песня «Догшн Замбл хаана һалзу долан бодңгиг Аср Улан Хоңһр Күнд һарта Савр хойр дөрәцүлгсн бөлг» ('O победе Улан Хонгора Могучего и Тяжелорукого Савара над семью неукротимыми вепрями [-богатырями] свирепого Замбалхана') относится к Багацохуровскому циклу калмыцкого эпоса.

В результате синоптического сопоставления пролога песни «Дуут богд Жаңһр догшн Хар Кинесиг дөрәцүлгсн бөлг» ('O том, как славный богдо Джангар свирепого Хара Кинеса покорил') и пролога песни «Догшн Замбл хаана һалзу долан бодңгиг Аср Улан Хоңһр Күнд һарта Савр хойр дөрәцүлгсн бөлг» ('О победе Улан Хонгора Могучего и Тяжелорукого Савара над семью неукротимыми вепрями [-богатырями] свирепого Замбал-хана') Багацохуровского цикла образовалось 1383 строчных позиций.

Синоптическая «развертка по вертикали» и сопоставление паритетных стихов выявили 153 стиха, совпадающих текстуально и позиционно. Для 105 стихов соответствия нашлись не рядом, а в других местах, на это указывает пометка см. с указанием номера строки, занимаемой в другом тексте тем же стихом. В 112 случаях стихи, хотя и различаются, но все же совпадают между собой, варьируя одну и ту же основу, в таблице у них стоит пометка $c p$. Совпадающих текстуально и позиционно, но с долей синонимии в деталях нами обнаружено 205 стихов. Вывод: 575 строчных позиций целиком и частично тождественны. Таким образом, в результате синоптического сопоставления двух записей пролога Багацохуровского цикла мы можем утверждать, что джангарчи, зная принципы сложения эпоса, строит свое повествование по определенной схеме, потому как абсолютное запоминание большого по объему текста невозможно.

Прежде чем исполнять эпос, джангарчи продумывает основу песни, строит её схему, некий план в определенном порядке. Так, при разборе пролога на составные части мы выявили следующую структуру:

1) магтал ('восхваление') страны;

2) сооружение дворца;

3) описание Джангара, его оружия и коня;

4) описание местоположения персонажей;

5) подчинение богатыря Савара;

6) пир во дворце Джангара;

7) восхваление страны.

Эти темы в свою очередь состоят из более дробных частей:

Тема «Магтал ('восхваление') страны» состоит из подтем:
а) гора Орог Йондон Орза;
б) гора Арслангин Алтай;
в) океан Шартаг;
г) бумбайские реки;
д) косогор Самба;
e) описание $3 y$.

Тема «Описание местоположения персонажей» состоит из таких подтем-описаний, как:

а) богатырь Очир Герел (только в песне «Замбал-хан»);

б) конюший Боро Мангна;

в) ханша Ага Герензел;

г) богатырь Алтан Чеджи;

д) богатырь Улан Хонгор;

е) богатырь Гюмбе.

Тема «Подчинение богатыря Савара» подразделяется на такие подтемы, как:

а) предсказание Алтан Чеджи;

б) отправление богатырей в путь;

в) обращение Ага Герензел к Улан Хонгору;

г) отправление Хонгора в поход;

д) побратимство богатьрей Хонгора и Савара.

Итак, синоптическое сопоставление текстов наглядно демонстрирует констант- 
ность эпического текста, а также позволяет проанализировать его вариативность.

Для сравнения константных и вариативных частей пролога мы составили таблицу № 2, в которой песни обозначены как: I. «О том, как славный богдо Джангар свирепого Хара Кинеса покорил»; II. «О победе Улан Хонгора Могучего и Тяжелорукого Савара над семью неукротимыми вепрями [-богатырями] свирепого Замбал-хана»).

Таблица № 2. Сравнение константных и вариативных частей пролога

\begin{tabular}{|c|c|c|c|}
\hline \multirow{3}{*}{ № } & \multirow{3}{*}{ Темы и подтемы } & \multicolumn{2}{|c|}{ В ари инты } \\
\hline & & \multicolumn{2}{|c|}{ Количество строк } \\
\hline & & I & II \\
\hline 1 & Магтал ('восхваление') страны: & & \\
\hline 2 & а) Гора Орог Йондон Орза; & 2 & 2 \\
\hline 3 & б) Гора Арслангин Алтай; & 3 & 3 \\
\hline 4 & в) Океан Шартаг; & 9 & 7 \\
\hline 5 & г) Бумбайские реки; & 10 & 4 \\
\hline 6 & д) Косогор Самба; & 5 & 4 \\
\hline 7 & е) Описание 3y. & 30 & 33 \\
\hline 8 & Сооружение дворца & 63 & 50 \\
\hline 9 & Описание Джангара, его оружия и коня & 132 & 195 \\
\hline 10 & Описание местоположения персонажей: & & \\
\hline 11 & а) Богатырь Очир Герел & - & 34 \\
\hline 12 & б) Конюший Боро Мангна; & 16 & 17 \\
\hline 13 & в) Ханша Ага Герензел; & 82 & 84 \\
\hline 14 & г) Богатырь Алтан Чеджи; & 17 & 12 \\
\hline 15 & д) Богатырь Улан Хонгор; & 58 & 49 \\
\hline 16 & е) Богатьрь Гюмбе. & 51 & 37 \\
\hline 17 & Подчинение богатыря Савара & 324 & 239 \\
\hline 18 & Пир во дворце Джангара & 62 & 34 \\
\hline 19 & Восхваление страны & 47 & 46 \\
\hline
\end{tabular}

В приведенной таблице мы видим, что уровень колебания текста в таких темах, как «Магтал ('восхваление') страны», «Сооружение дворца», «Восхваление страны», невелик. В песне «Хара Кинес» в теме «Описание местоположения персонажей» отсутствует подтема «Богатырь Очир Герел», в остальных подтемах наблюдается небольшое варьирование. Исключением является тема «Подчинение богатыря Савара»: абсолютно тождественны 30 стихов, совпадающих текстуально и позиционно, но с долей синонимии в деталях нами обнаружено 60 стихов, разница в 85 стихов объясняется тем, что в песне «Хара Кинес» присутствуют такие типические места, как «описание коня», «седлание коня», «одева- ние богатыря», «выезд богатыря», тогда как в песне «Замбал-хана» эти описания сокращены, а в некоторых случаях отсутствуют вовсе.

В связи с невозможностью представить в данной статье таблицу полного синоптического сопоставления двух прологов Багацохуровского цикла, которая занимает более 120 страниц, ниже мы приводим лишь еe фрагмент (см. табл. № 2; перевод калмыцкого текста на русский язык осуществлен сотрудником Калмыцкого научного центра РАН Т. А. Михалевой). Приведенная ниже таблица синоптического сопоставления констатирует сохранность «поэтической фактуры» стихов с некоторыми изменениями типических мест и формул. 
Таблица № 2. Сравнение двух прологов Багачохуровского ичикла

\begin{tabular}{|c|c|c|}
\hline & $\begin{array}{l}\text { I. ДУУТ БОГД ЖАНЬР ДОГШН ХАР } \\
\text { КИНЕСИГ ДӨРӘЦҮЛГСН БӨЛГ }\end{array}$ & $\begin{array}{l}\text { II. ДОГШН ЗАМБЛ ХААНА ҺАЛЗУ ДОЛАН } \\
\text { БОДНГИГ АСР УЛАН ХОННР КҮНД ҺАРТА } \\
\text { САВР ХОЙР ДӨРӘЦҮЛГСН БӨЛГ }\end{array}$ \\
\hline 1. & $\begin{array}{l}\text { Олн бум бурхн үд дунднь үдлгсн } \\
\text { 'Сотни тысяч бурханов в полдень пребывают } \\
\text { в покое' }\end{array}$ & $\begin{array}{l}\text { Бум олн бурхн / Үд дунднь үдлгсн } \\
\text { 'Сотни тысяч бурханов / В полдень пребывают } \\
\text { в покое' }\end{array}$ \\
\hline 2. & \multicolumn{2}{|c|}{$\begin{array}{c}\text { Орг Йондн Орз гилә. } \\
\text { ‘[На горе] Орог Йондон Орза, говорили’. }\end{array}$} \\
\hline 3. & $\begin{array}{l}\text { Арслң Алта мөңгн Цаһан уул } \\
\text { ‘Богатырского Алтая серебристая гора Цаган' }\end{array}$ & $\begin{array}{l}\text { Арслң Алта мөңгн Цаһан уулнь } \\
\text { 'Богатырского Алтая серебристая гора Цаган' }\end{array}$ \\
\hline 4. & \multicolumn{2}{|c|}{$\begin{array}{c}\text { Һарх шар нарни көлд } \\
\text { 'В лучах восходящего жёлтого солнца', }\end{array}$} \\
\hline 5. & \multicolumn{2}{|c|}{$\begin{array}{l}\text { һазр, теңгрин киисн болад, маңхаһад бәәдгж. } \\
\text { 'Будто пупом земли и неба став, величаво высится'. }\end{array}$} \\
\hline 6. & \multicolumn{2}{|c|}{$\begin{array}{c}\text { Өргн Шартг далань } \\
\text { 'Широкий океан Шартаг' }\end{array}$} \\
\hline 7. & \multicolumn{2}{|c|}{$\begin{array}{l}\text { Өру сөру хойр урсх[у]лта, } \\
\text { 'Прилив и отлив - два течения имеет', }\end{array}$} \\
\hline 8. & \multicolumn{2}{|c|}{$\begin{array}{l}\text { Үлдән мөргәр (II. мөргн) дольгалдг (II. дольгата), } \\
\text { 'Обуху меча подобны волны его', }\end{array}$} \\
\hline 9. & \multicolumn{2}{|c|}{$\begin{array}{l}\text { Шур сувсн (I. хойр) күрлһтә, } \\
\text { 'Кораллами и жемчугами он богат', }\end{array}$} \\
\hline 10. & \multicolumn{2}{|c|}{$\begin{array}{c}\text { Элдв бадмин өңгтә. } \\
\text { ‘Красивых лотосов цвет он имеет’. }\end{array}$} \\
\hline 11. & $\begin{array}{l}\text { Эн далан уснас уугсн күмн } \\
\text { 'Воду этого океана кто выпьет', }\end{array}$ & $\begin{array}{l}\text { Эрднь Шартг далань } \\
\text { ‘Драгоценный океан Шартаг’, }\end{array}$ \\
\hline 12. & - & $\begin{array}{l}\text { Манн болж туннал. } \\
\text { ‘Дымясь туманом, покоится’. }\end{array}$ \\
\hline 13. & - & $\begin{array}{l}\text { Эгц нәәмн миңһн һолнь } \\
\text { 'Ровно восемь тысяч рек' }\end{array}$ \\
\hline 14. & $\begin{array}{l}\text { Үкл уга мөңк, } \\
\text { ‘Вовеки бессмертным становится', }\end{array}$ & См. 1336 \\
\hline 15. & $\begin{array}{l}\text { Үксн цагтан } \\
\text { 'Но когда умрёт', }\end{array}$ & См. 53 \\
\hline 16. & $\begin{array}{l}\text { Үрглж[д] hучн hурвн теңгрин орнд төрдг. } \\
\text { 'Непременно в стране тридцати трёх } \\
\text { тенгриев перерождается'. }\end{array}$ & См. 54 \\
\hline 17. & $\begin{array}{l}\text { Салгсн нәәмн миңһн һолнь } \\
\text { 'Восемь тысяч рек, ответвленные [от } \\
\text { океана]', }\end{array}$ & Cp. 13 \\
\hline 18. & $\begin{array}{l}\text { Дөчн сай алвтинән үүдн болһнднь } \\
\text { 'Мимо дверей каждого из сорока миллионов } \\
\text { подданных', }\end{array}$ & $\begin{array}{l}\text { Дөчн түмн алвтани үүдн болһарнь } \\
\text { 'Мимо дверей каждого из сорока туменов } \\
\text { подданных' }\end{array}$ \\
\hline 19. & $\begin{array}{l}\text { Көрл уга, мөңк дөрвн цагт } \\
\text { 'Не замерзая, в вечные четыре времени } \\
\text { [года]' }\end{array}$ & $\begin{array}{l}\text { Мөңк дөрвн цагт } \\
\text { 'В вечные четыре времени [года]' }\end{array}$ \\
\hline 20. & $\begin{array}{r}\text { Элсн сәәрһләр ж } \\
\text { 'По песчаным руслам }\end{array}$ & $\begin{array}{l}\text { иржжннж гүүһәд, } \\
\text {, журча ручьём, текут }\end{array}$ \\
\hline 21. & $\begin{array}{r}\text { Услур түгәж өгдг ( } \\
\text { 'И поят вод } \\
\end{array}$ & $\begin{array}{l}\text { II. өгнәл) (І. гинә). } \\
\text { ой, говорят'. }\end{array}$ \\
\hline 22. & $\begin{array}{l}\text { Эзн Жаңһрин эврәни услурнь - } \\
\text { 'Сам владыка Джангар пьёт' }\end{array}$ & - \\
\hline 23. & $\begin{array}{l}\text { Киитн Домб гидг һолнь - } \\
\text { 'Из студёной реки Домбо — }\end{array}$ & Cp. 386 \\
\hline
\end{tabular}




\begin{tabular}{|c|c|c|}
\hline 24. & $\begin{array}{l}\text { Асрин улан эңгән хольв цокад, } \\
\text { 'Высокий красный яр подмывая,' }\end{array}$ & - \\
\hline 25. & $\begin{array}{l}\text { Мөңкән дөрвн цагт } \\
\text { 'В вечные четыре времени [года]' }\end{array}$ & См. 19 \\
\hline 26. & $\begin{array}{l}\text { Көрл уга бәәдг гинә. } \\
\text { 'Не замерзает [она], говорят'. }\end{array}$ & Cp. 19 \\
\hline 27. & $\begin{array}{l}\text { Өл Самбан ташу гидгнь - } \\
\text { 'Седой Самба [горы] склон,' }\end{array}$ & $\begin{array}{l}\text { Өл Самбан ташуднь } \\
\text { 'На склоне седой Самба [горы]' }\end{array}$ \\
\hline 28. & $\begin{array}{l}\text { Баатрмуднь агтан тәвдг, } \\
\text { 'Куда богатыри коней [пастись] отпускают,' }\end{array}$ & - \\
\hline 29. & \multicolumn{2}{|c|}{$\begin{array}{c}\text { Үвл, зун уга } \\
\text { Зимой и летом } \\
\end{array}$} \\
\hline 30. & $\begin{array}{l}\text { Үрглж[д] хумха уга көк, } \\
\text { ‘Покрыт неувядающей зелёной травой', }\end{array}$ & \begin{tabular}{|l|} 
Өвсни көк \\
'Травы зелёные'
\end{tabular} \\
\hline 31. & $\begin{array}{l}\text { Маанин аюһар һаңхдг болна. } \\
\text { ‘Колышущейся, будто вторя пению молитв'. }\end{array}$ & $\begin{array}{l}\text { Үрглж[д] маанин аюһар һаңхнал. } \\
\text { 'Колышутся, будто вторя пению молитв’. }\end{array}$ \\
\hline 32. & \multicolumn{2}{|c|}{$\begin{array}{c}\text { Зу талнь хәләхнь, } \\
\text { 'Если в сторону } 3 \text { посмотреть,' }\end{array}$} \\
\hline 33. & \multicolumn{2}{|c|}{$\begin{array}{c}\text { Зурһан миңһн шар алтн сүмнь } \\
\text { 'Шесть тысяч жёлто-золотистых храмов' }\end{array}$} \\
\hline 34. & \multicolumn{2}{|c|}{$\begin{array}{l}\text { Зүүгин хар үүлнәс ивт юуһинь һар[h]ад, } \\
\text { 'Пронзая чёрные тучи, оттуда плывущие,' }\end{array}$} \\
\hline 35. & \multicolumn{2}{|c|}{$\begin{array}{c}\text { Одта көк теңгрин аһарт (II.-нь), } \\
\text { 'В звёздного синего неба просторах,' }\end{array}$} \\
\hline 36. & \multicolumn{2}{|c|}{$\begin{array}{l}\text { Орх шар нарни (I. зүн өнцг көл дорнь) көлднь } \\
\text { 'Левее лучей заходящего жёлтого солнца' }\end{array}$} \\
\hline 37. & \multicolumn{2}{|c|}{$\begin{array}{c}\text { Бел белән түшв (II. түшч харгднал). } \\
\text { 'Вплотную друг к другу стоят'. }\end{array}$} \\
\hline 38. & \multicolumn{2}{|c|}{$\begin{array}{l}\text { Шат болгсн (I. Бумб далан көвәднь) бумблва[д]нь } \\
\text { 'На берегу Бумбы-океана с уступами' }\end{array}$} \\
\hline 39. & \multicolumn{2}{|c|}{$\begin{array}{c}\text { Шартг дөрвн далата, } \\
\text { 'Жёлтых четыре моря имеющие, }\end{array}$} \\
\hline 40. & \multicolumn{2}{|c|}{$\begin{array}{c}\text { Шарин дөрвн киидтә, } \\
\text { 'Жёлтой веры четыре монастыря имеющие,' }\end{array}$} \\
\hline 41. & \multicolumn{2}{|c|}{$\begin{array}{c}\text { Шагжмунин илтә хүвлһән бламта } \\
\text { ‘Ламу - перерожденца Шакьямуни - имеющие' }\end{array}$} \\
\hline 42. & $\begin{array}{l}\text { Шагжмунин тоота долан түмн хувргнь } \\
\text { 'Шакьямуни последователи, семьдесят } \\
\text { тысяч хувараков,' }\end{array}$ & $\begin{array}{l}\text { Шажин тоота нәәмн түмн шевнрнь } \\
\text { 'Священнослужители, восемьдесят тысяч } \\
\text { шабинеров,' }\end{array}$ \\
\hline 43. & \multicolumn{2}{|c|}{$\begin{array}{l}\text { Шатр болгсн (II. бумблвадан) орд харшдан } \\
\text { 'Во дворце своём, шатру подобном,' }\end{array}$} \\
\hline 44. & - & \begin{tabular}{|l|} 
Шаңхлһан хәләж, \\
'В свитки посматривая,'
\end{tabular} \\
\hline 45. & $\begin{array}{l}\text { Шар улан хойрнь йилһрәд, } \\
\text { 'На жёлтых и красных разделившись,' }\end{array}$ & $\begin{array}{l}\text { Шар, улань йилһрж, } \\
\text { 'На жёлтых и красных разделившись,' }\end{array}$ \\
\hline 46. & \multicolumn{2}{|c|}{$\begin{array}{c}\text { Увр-увр гилдвл. } \\
\text { ‘[Молитвы] читают’. }\end{array}$} \\
\hline 47. & \multicolumn{2}{|c|}{$\begin{array}{c}\text { Дун, бүрәһин дунь } \\
\text { Звуки их раковин и труб' }\end{array}$} \\
\hline 48. & $\begin{array}{l}\text { Догшн хату дән нутгт } \\
\text { 'В жестокой вражеской стране,' }\end{array}$ & $\begin{array}{l}\text { Дорд Замбан орнд } \\
\text { 'В восточной замбайской стране,' }\end{array}$ \\
\hline 49. & $\begin{array}{l}\text { Күңкнж соңсгдв, } \\
\text { ‘Эхом отдаваясь, слышались'. }\end{array}$ & 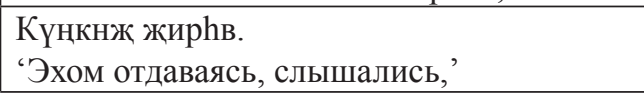 \\
\hline
\end{tabular}




\begin{tabular}{|c|c|c|}
\hline 50. & \multicolumn{2}{|c|}{$\begin{array}{c}\text { Догшд номинин яңнь (II. ценглгнь ) } \\
\text { Их духовные песнопения во славу докшитов, }\end{array}$} \\
\hline 51. & $\begin{array}{l}\text { Деер, теңгрин орнд жиржңнж соңсгддг болна. } \\
\text { 'Наверху, в стране тенгриев, как журчание, } \\
\text { слышались. }\end{array}$ & $\begin{array}{l}\text { Һучн hурвн Хурмстын [теңгрин] аһартнь } \\
\text { соңсгдв. } \\
\text { 'В обители тридцати трёх [тенгриев] } \\
\text { Хормусты слышались'. }\end{array}$ \\
\hline 52. & \multicolumn{2}{|c|}{$\begin{array}{l}\text { Үзл уга мөрггсн (II. үнмнгсн) күмн } \\
\text { 'Кто, не видя [этого], молится,' }\end{array}$} \\
\hline 53. & \multicolumn{2}{|c|}{$\begin{array}{l}\text { Үксн цагтан } \\
\text { 'Когда умрёт,' }\end{array}$} \\
\hline 54. & \multicolumn{2}{|c|}{$\begin{array}{c}\text { Үрглжд һучн һурвн теңгрин орнд (II. теңгрт) төрдг (I. гинә), } \\
\text { 'Непременно в стране тридцати трёх тенгриев перерождается, говорят,' }\end{array}$} \\
\hline 55. & \multicolumn{2}{|c|}{$\begin{array}{l}\text { Үзәд, эргәд мөрггсн (II. седклән тәвгсн) күмн } \\
\text { 'Кто видит [это] и совершает обход [храмов],' }\end{array}$} \\
\hline 56. & $\begin{array}{l}\text { Эсрң теңгрин деер, миңһн берән һазрт, } \\
\text { 'Тот в будущем на небесах, на расстоянии } \\
\text { тысячи беря, }\end{array}$ & $\begin{array}{l}\text { Эсрң теңгрин деер, } \\
\text { 'Тот в будущем на небесах,' }\end{array}$ \\
\hline 57. & $\begin{array}{l}\text { Эрдни Ө бурхни таралнднь } \\
\text { 'В обители благородного бурхана }\end{array}$ & $\begin{array}{l}\text { Эрднь бурхни таралңд, } \\
\text { 'В обители благородного бурхана,' }\end{array}$ \\
\hline 58. & $\begin{array}{l}\text { Эгц миңһн һалвд } \\
\text { ‘В тысячелетия раз }\end{array}$ & - \\
\hline 59. & \multicolumn{2}{|c|}{$\begin{array}{c}\text { Эрк биш төрдг андһарта (I. гинә). } \\
\text { 'Непременно переродиться судьбу имеет, (I. говорят)'. }\end{array}$} \\
\hline 60 & $\begin{array}{l}\text { Шат болгсн Бумб далан көвәд орулж авгсн } \\
\text { 'На берегу Бумбы-океана с уступами }\end{array}$ & Cp. 1329 \\
\hline 61. & - & $\begin{array}{l}\text { Эзн деед богдын күрә, киидд } \\
\text { 'Владыки верховного богдо монастыри и } \\
\text { храмы’ }\end{array}$ \\
\hline 62. & - & $\begin{array}{l}\text { Нарта делкән орнд, } \\
\text { 'На всём белом свете,' }\end{array}$ \\
\hline 63. & - & $\begin{array}{l}\text { Нәәмн миңһн ик хаани нутгтнь һәәхүл болнал. } \\
\text { 'Во владениях восьми тысяч великих ханов } \\
\text { дивом являются'. }\end{array}$ \\
\hline 64. & - & $\begin{array}{l}\text { Бумб далан } \\
\text { ‘[Ответвленных от] Бумбы-океана,' }\end{array}$ \\
\hline 65. & - & $\begin{array}{l}\text { hучн hурвн һолын экнд орулж авгсн } \\
\text { 'Покорённых у истоков тридцати трёх рек,' }\end{array}$ \\
\hline 66. & \begin{tabular}{l}
\multicolumn{2}{l}{ Шалдг дөрвн миңһн хан } \\
'Покорённые \\
избранников
\end{tabular} & $\begin{array}{l}\text { Шарин дөрвн түмн маңһс[и]нь } \\
\text { 'Жёлтой веры четыре тумена мангасов,' }\end{array}$ \\
\hline 67. & $\begin{array}{l}\text { Алвттаһан багтн ядв, } \\
\text { 'С подданными своими не могли } \\
\text { разместиться. }\end{array}$ & $\begin{array}{l}\text { Шахж тулв. } \\
\text { ‘Притесняя, подавляли’. }\end{array}$ \\
\hline 68. & $\begin{array}{r}\text { Эрцс Бумбан бум h } \\
\text { 'На берегу извилистой Бумбы [p }\end{array}$ & $\begin{array}{l}\text { олд (II. һолын экнд) } \\
\text { реки] со ста тысячами притоков, }\end{array}$ \\
\hline 69. & $\begin{array}{r}\text { Эзн Жаңһри } \\
\text { 'Владыке }\end{array}$ & $\begin{array}{l}\text { н эврән меддг } \\
\text { Джангару' }\end{array}$ \\
\hline 70. & $\begin{array}{r}\text { (II. Элвг) дал } \\
\text { 'Принадлежащие семьд }\end{array}$ & $\begin{array}{l}\text { н келн алвтнь } \\
\text { есят племён подданных,' }\end{array}$ \\
\hline 71 & $\begin{array}{l}\text { Долан сарин һазрт багтж ядад, } \\
\text { 'На пространстве семи месяцев пути не } \\
\text { поместившись,' }\end{array}$ & - \\
\hline
\end{tabular}


Oriental Studies, 2018, Vol. 39, Is. 5

\begin{tabular}{|c|c|c|}
\hline 72. & $\begin{array}{l}\text { Жаңһрин нерәр } \\
\text { ‘Джангара именем [устрашая],' }\end{array}$ & $\begin{array}{l}\text { Эзн богд Жаңһрин нерәрнь } \\
\text { 'Владыки } \\
\text { [устрашая], }\end{array}$ \\
\hline 73. & $\begin{array}{l}\text { Шарин дөрвн түмн орни һазринь } \\
\text { ‘Жёлтой веры сорок тысяч стран’ }\end{array}$ & $\begin{array}{l}\text { Шарин дөрвн түмн хааг } \\
\text { 'Жёлтой веры четыре тумена ханов’, }\end{array}$ \\
\hline 74. & $\begin{array}{l}\text { Булаж авад, шахж генүлв. } \\
\text { ‘Захватив, притесняли [народ]’. }\end{array}$ & $\begin{array}{l}\text { Һазринь булаж авад шахж генүлв. } \\
\text { 'Владения их захватив, притесняли'. }\end{array}$ \\
\hline 75. & - & $\begin{array}{l}\text { Бумб далан живхлңднь, } \\
\text { '[На берегу] величественного океана Бумбы,' }\end{array}$ \\
\hline 76. & \multicolumn{2}{|c|}{$\begin{array}{l}\text { hарх шар нарни зүн өнцг көлднь, } \\
\text { ‘Левее лучей восходящего жёлтого солнца,' }\end{array}$} \\
\hline 77. & $\begin{array}{l}\text { Һандиг Алта ууланин ар тавцнднь, } \\
\text { 'На северном склоне своей высокой горы } \\
\text { Алтай,' }\end{array}$ & $\begin{array}{l}\text { hаслңта жирн зурһан теңгсин цутхлнднь, } \\
\text { 'у слияния шестидесяти шести бурных } \\
\text { морей,' }\end{array}$ \\
\hline 78 & $\begin{array}{l}\text { hаслцт жирн зурһан теңгсин цудхлһнднь } \\
\text { 'у слияния шестидесяти шести бурных } \\
\text { морей' }\end{array}$ & $\begin{array}{l}\text { Һандиг Алта уулын ар тавцң деернь } \\
\text { ‘На северном склоне высокой горы Алтай’ }\end{array}$ \\
\hline 79. & \multicolumn{2}{|c|}{$\begin{array}{c}\text { Шахр алтн бәәшңгән шин делдүлв. } \\
\text { 'Дворец из чистого золота только что [Джангар] воздвиг’. }\end{array}$} \\
\hline 80. & $\begin{array}{l}\text { Шарин дөрвн зүгин өргә } \\
\text { 'Жёлтой веры ставками четырёх сторон’ }\end{array}$ & $\begin{array}{l}\text { Шажин нәәмн түмн маңһсиг } \\
\text { 'Верующих восемь туменов мангасов' }\end{array}$ \\
\hline 81. & $\begin{array}{l}\text { Эврәһән кеж орулж авб. } \\
\text { ‘Завладел, себе он их подчинил,' }\end{array}$ & $\begin{array}{l}\text { Номдан орулж авб, } \\
\text { 'В веру свою обратил,' }\end{array}$ \\
\hline 82. & - & $\begin{array}{l}\text { Дөрвн үзгин эзн болв, } \\
\text { 'В четырёх сторонах владыкой он стал,' }\end{array}$ \\
\hline 83 & - & $\begin{array}{l}\text { Дүүвр һәрдин нутган төвкнүлн тогтав, } \\
\text { 'В его гордой стране покой воцарился,' }\end{array}$ \\
\hline 84 & \multicolumn{2}{|c|}{$\begin{array}{c}\text { Йиртмжин төриг хад мет бәəһүлв, } \\
\text { 'Вселенскую державу свою, как скалу, укрепил,' }\end{array}$} \\
\hline 85 & \multicolumn{2}{|c|}{$\begin{array}{l}\text { Бурхни шажиг нарн мет мандлулв (II. делгрүлв). } \\
\text { 'Бурханов веру, как солнце, возвеличил [он]'. }\end{array}$} \\
\hline
\end{tabular}

Рассмотрение прологов подтверждает положение о том, что «каждый текст вбирает в себя и готовую, лексически устойчивую часть» [Гацак 1971: 46], и в вербальном воплощении, естественно, может варьироваться. Джангарчи, усвоивший эпос у своего предшественника, хранит в своей памяти готовый набор формул, типических мест и т. д. Но при устном воспроизведении рапсод строит свое повествование каждый раз по-новому, потому как «у певца не одна повествовательная возможность, а „пучок“ таких возможностей» [Гацак 1971: 45].

Таким образом, анализ текста обнаруживает варьирование при описании Джангара и его коня, месторасположения богатырей, подчинения богатыря Савара, пира во дворце Джангара (см. табл. № 2).

Варьирование словесной ткани текста наблюдается в следующих случаях:

a) изменяемость формул;

б) перестановка слов в стихотворной строке;

в) редукция и амплификация.

В результате анализа мы обнаружили, что основные различия наблюдаются в морфологических, фонетических изменениях, перестановках тем и подтем, смене времени, синонимической замене слов и других трансформациях. Отдельные слова, фразеологические сочетания заменяются синонимами, контекстуальными синонимами (см. табл. 3, табл. 4). 
Таблица № 3. Примеры синонимической замены в двух прологах песен «Джангар»

\begin{tabular}{|c|c|}
\hline I & II \\
\hline $\begin{array}{l}\text { хумха уга көк } \\
\text { 'неувядающей зелёной травой' }\end{array}$ & $\begin{array}{l}\text { өвсни көк } \\
\text { ‘травы зелёные' }\end{array}$ \\
\hline $\begin{array}{l}\text { Догшн хату дән нутгт } \\
\text { 'В жестокой вражеской стране' }\end{array}$ & $\begin{array}{l}\text { Дорд Замбан орнд } \\
\text { 'В восточной замбайской стране', }\end{array}$ \\
\hline $\begin{array}{l}\text { Күнџкнжс соңсгддв } \\
\text { 'Эхом отдаваясь, слышались' }\end{array}$ & $\begin{array}{l}\text { Күңзкнж, жсирһв } \\
\text { 'Эхом отдаваясь, слышались' }\end{array}$ \\
\hline $\begin{array}{l}\text { тензгрин орнд } \\
\text { 'в стране тенгриев' }\end{array}$ & $\begin{array}{l}\text { тенцгрин аһартнь } \\
\text { 'в стране тенгриев' }\end{array}$ \\
\hline $\begin{array}{l}\text { Эрдни Ө бурхни таралцднь } \\
\text { 'В обители благородного бурхана' }\end{array}$ & $\begin{array}{l}\text { Эрднь бурхни таралщуд } \\
\text { 'В обители благородного бурхана' }\end{array}$ \\
\hline $\begin{array}{l}\text { багтн ядв } \\
\text { 'не могли разместиться' }\end{array}$ & $\begin{array}{l}\text { шахжс тулв } \\
\text { 'притесняя, подавляли’ }\end{array}$ \\
\hline $\begin{array}{l}\text { Шарин дөрвн түмн орни hазринь } \\
\text { 'Жёлтой веры сорок тысяч стран' }\end{array}$ & $\begin{array}{l}\text { Шарин дөрвн түмн хааг } \\
\text { 'Жёлтой веры четыре тумена ханов’ }\end{array}$ \\
\hline $\begin{array}{l}\text { Эврәһән кежс орулжс авб } \\
\text { ‘Завладел, себе он их подчинил’ }\end{array}$ & $\begin{array}{l}\text { Номдан орулжс авб } \\
\text { 'В веру свою обратил' }\end{array}$ \\
\hline $\begin{array}{l}\text { Дөчн сай алвтинән } \\
\text { 'сорока миллионов подданных’ }\end{array}$ & $\begin{array}{l}\text { Дөчн түмн алвтани } \\
\text { 'сорока туменов подданных' }\end{array}$ \\
\hline $\begin{array}{l}\text { долан түмн хувргнь } \\
\text { 'семьдесят тысяч хувараков' }\end{array}$ & $\begin{array}{l}\text { ндамн түмн шевнрнь } \\
\text { 'восемьдесят тысяч щабинеров' }\end{array}$ \\
\hline $\begin{array}{l}\text { Шалдг дөрвн миңһн хан } \\
\text { 'Покорённые четыре тысячи ханов-избранников' }\end{array}$ & $\begin{array}{l}\text { Шарин дөрвн түмн манһс[и]нь } \\
\text { 'Жёлтой веры четыре тумена мангасов' }\end{array}$ \\
\hline $\begin{array}{l}\text { Шарин дөрвн зүгин өргә } \\
\text { 'Жёлтой веры ставками четырёх сторон' }\end{array}$ & $\begin{array}{l}\text { Шажчин ндамн түмн маңһһсиг } \\
\text { 'Верующих восемь туменов мангасов' }\end{array}$ \\
\hline
\end{tabular}

Приведенные синонимические параллели не являются тавтологическими сочетаниями и не синонимы в словарном смысле, они оказываются синонимами только потому, что функционально несут одинаковую смысловую нагрузку, выполняют функцию асимметричных синонимов, уподобленных и одновременно расподобленных. «Поэтическая же их функция в контексте не изображать, а обозначать нечто при помощи сопоставления этих выделенных качеств» [Чистов 1983: 169]. В сопоставляемых текстах синонимы представляют общефольклорную и общеязыковую традиции.

Калмыцкие джангарчи придерживались традиции «петь, как старики пели», в силу консервативности эпической школы рапсоды не могли импровизировать и вносить что-то новое. Слушая эпос, певец перенимал у своего предшественника традиционный и стандартизированный набор сюжетов, стилистических и композиционных приемов, которые он использовал во время исполнения «Джангара».

Пролог, являясь гениальной находкой певцов эпоса, свидетельствует о высшем достижении эпического мастерства рапсодов, благодаря которым «Джангар» coxpa- нился и стал мировым художественным наследием.

\section{ИСТОЧНИКИ / SOURCES}

Golstunsky Collection - 908 Incipit: (f. 1a) Olon bum burxan üde dumduni üdelegsen:... Calm. C. 17, inventory No. 1770. Old call number Xyl. F 63. Golstunsky Collection (1857), No. 2. / Библиотека Восточного факультета СПбГУ. [908 Incipit: (f. 1a) Olon bum burxan üde dumduni üdelegsen:... Calm. C. 17, inventory No. 1770. Old call number Xyl. F 63. Golstunsky Collection (1857), No. 2. Library of Faculty of Asian and African Studies, St. Petersburg State University.]

Jangar 1864 - Jangar: Dogshin Shara Gurguugiyin bolog; Dogshin Qara Kineesiyin bolog // Ubasi qun tayijiyin tuuji; Jangar; Sidiyitu kuuriyin tuuli / изд. К. Голстунский. СПб., 1864. С. 8-74. На старописьм. калм. [Jangar: Dogshin Shara Gurguugiyin bolog; Dogshin Qara Kineesiyin bolog // Ubasi qun tayijiyin tuuji; Jangar; Sidiyitu kuuriyin tuuli / K. Golstunsky (publ.). St. Petersburg, 1864. Pp. 8-74. (In Old Kalm.)] НА РГО - Научный архив РГО СПб. ОП. 1. Д. № 15 «Песни и сказки калмыцкого народа Астраханской губернии Багацохуров- 
ского улуса». [Nauchnyi arkhiv RGO SPb [Scientific Archive of St. Petersburg Office of the Russian Geographical Society]. Ser. 1. File No. 15: 'Songs and tales of the Kalmyk people inhabiting Bagatsokhurovsky Ulus of Astrakhan Governorate'. (In Old Kalm.)]

Джангар 1990 - Джангар: Калмыцкий героический эпос / сост., подг. текстов, коммент. и словарь Н. Ц. Биткеева, Э. Б. Овалова, Ц. К. Корсункиева и др.; прилож.: Калм. героич. эпос “Джангар”. М.: Наука, ГРВЛ, 1990. 474 с. На калм. и рус. яз. (Серия “Эпос народов СССР”). [Dzhangar: Kalmytskiy geroicheskiy epos [The Kalmyk heroic epic of Jangar]. N. Ts. Bitkeev, E. B. Ovalov, Ts. K. Korsunkiev et al. (comp., prep., etc.). Moscow: Nauka, 1990. 474 p. (In Kalm. and Rus.)]

\section{ЛИТЕРАТУРА / REFERENCES}

Гацак 1971 - Гаичак В. М. Эпический певец и его текст // Текстологическое изучение эпоса. М.: Наука, 1971. С. 7-46. [Gatsak V. M. The epic taleteller and his text. Tekstologicheskoe izuchenie eposa [Textological studies of epic texts]. Moscow: Nauka, 1971. Pp. 7-46. (In Rus.)]

Гацак 1989 - Гацак В. М. Устная эпическая традиция во времени: Историческое исследование поэтики. М.: Наука, 1989. 256 с. [Gatsak V. M. Ustnaya epicheskaya traditsiya vo vremeni: Istoricheskoe issledovanie poetiki [The oral epic tradition in time: a historical study of poetics]. Moscow: Nauka, 1989. 256 p. (In Rus.)]

Кичиков 1992 - Кичиков А. Ш. Героический эпос «Джангар». Сравнительно-типологическое исследование памятника. М.: Вост. лит., 1992. 320 с. [Kichikov A. Sh. Geroicheskiy epos «Dzhangar». Sravnitel'notipologicheskoe issledovanie pamyatnika [The heroic epic of Jangar: a comparative and typological study]. Moscow: Vost. Lit., 1992. 320 p. (In Rus.)]

Козин 1940 - Козин С. А. «Джангариада». Героическая поэма калмыков (введение в изучение памятника и перевод торгутской его версии). М.; Л., 1940. 252 с. [Kozin S. A. «Dzhangariada». Geroicheskaya poema kalmykov (vvedenie $v$ izuchenie pamyatnika $i$ perevod torgutskoy ego versii) [The Jangariada: a heroic poem of the Kalmyks]. Moscow; Leningrad, 1940. 252 p. (In Rus.)]

Манджиева 2003 - Манджиева Б. Б. Пролог Малодербетовской версии (1862 г.) (Синоптический разбор трех вариантов) // «Монголоведение в новом тысячелетии (к 170-ле- тию организации первой кафедры монгольского языка в России)» Мат-лы Междунар. науч. конф. Элиста: КалмГУ, 2003. С. 140141. [Mandzhieva B. B. The Baya Dorbet version (1862) of the Jangar epic: a prologue. «Mongolovedenie v novom tysyacheletii» [Mongol Studies in the New Millennium]. Conf. proc. Elista: Kalmyk State Univ., 2003. Pp. 140-141. (In Rus.)]

Манджиева 2004a - Манджиева Б. Б. Пролог в поэтико-стилевой традиции «Джангара» (Малодербетовская версия 1862 г.): дис. ... канд. филол. наук. Москва, 2004а. 159 с. [Mandzhieva B. B. Prolog v poetiko-stilevoy traditsii «Dzangara» (Maloderbetovskâ̂ versiâ 1862 g.) [The epic of Jangar: a prologue in the poetic and stylistic tradition (Baya Dorbet version of 1862)]. A $\mathrm{PhD}$ thesis. Moscow, 2004a. 159 p. (In Rus.)].

Манджиева 2004б - Манджиева Б. Б. Пролог в поэтико-стилевой традиции «Джангара» (Малодербетовская версия 1862 г.): автореф. дис. ... канд. филол. наук. Москва, 2004б. 19 c. [Mandzhieva B. B. Prolog v poetiko-stilevoy traditsii «Dzhangara» (Maloderbetovskaya versiya 1862 g.) [The epic of Jangar: a prologue in the poetic and stylistic tradition (Baya Dorbet version of 1862)]. A PhD thesis abstract. Moscow, 2004b. 19 p. (In Rus.)]

Манджиева 2014 - Манджиева Б. Б. Роль пролога в композиции калмыцкого героического эпоса «Джангар» // «Epic Jangar and Beyond». Мат-лы междунар. науч. конф. (г. Хобуксар, 16-17 июля 2014 г.). Хобуксар, 2014. С. 209216. [Mandzhieva B. B. The role of a prologue within the structure of the Kalmyk heroic epic of Jangar. «Epic Jangar and Beyond». Conf. proc. (Hoboksar, 16-17 July 2014). Hoboksar, 2014. Pp. 209-216. (In Rus.)]

Манджиева 2015 - Манджиева Б. Б. К вопросу изучения калмыцких богатырских сказок // XLIV Междунар. филолог. науч. конф. Тезисы докладов. СПб.: СПбГУ, 2015. C. 741-742. [Mandzhieva B. B. Studies of Kalmyk heroic tales revisited. $44^{\text {th }}$ Internat. philolog. conf. Conf. abstracts. St. Petersburg: St. Petersburg State Univ., 2015. Pp. 741-742. (In Rus.)]

Овалов 1977 - Овалов Э. Б. Поэма о поражении свирепого Хара Киняса в эпосе «Джангар». Элиста: Калм. кн. изд-во, 1977. 79 с. [Ovalov E. B. Poema o porazhenii svirepogo Khara Kinyasa v epose «Dzhangar» [The epic of Jangar: a Song (poem) about the Defeat of Khara Kinyas the Fierce]. Elista: Kalm. Book Publ., 1977. 79 p. (In Rus.)] 
Убушиева 2009 - Убушиева Д. В. Багацохуровский цикл «Джангара» в записях XIX века (сюжетика и сохранность эпического текста): автореф. дис. ... канд. филол. наук. Элиста, 2009. 21 с. [Ubushieva D. V. Bagatsokhurovskiy tsikl «Dzhangara»v zapisyakh XIX veka (syuzhetika i sokhrannost' epicheskogo teksta) [The Baya Tsokhor cycle of the Jangar epic: $19^{\text {th }}$ century records]. A PhD thesis abstract. Elista, 2009. 21 p. (In Rus.)]

Убушиева 2012 - Убушиева Д. В. Сохранность и вариативность эпического текста (материал трех разносюжетных песен Багацохуровского цикла калмыцкого героического эпоса «Джангар») // Научное наследие профессора А. Ш. Кичикова и актуальные проблемы современной калмыцкой филологии и культуры. Мат-лы регион. науч. конф., посвящ. 90-летию со дня рождения профессора А. Ш. Кичикова. 2012. С. 133-135. [Ubushieva D. V. Integrity and variability of the epic text: a case study of three songs of the Baya Tsokhor cycle. «Nauchnoe nasledie professora A. Sh. Kichikova $i$ aktual'nye problemy sovremennoy kalmytskoy filologii i kul'tury» [Scientific heritage of Prof. A. Kichikov and topical challenges of contemporary Kalmyk linguistic and cultural studies]. Conf. proc. 2012. Pp. 133-135. (In Rus.)]

Убушиева 2016а - Убушиева Д. В. Пролог Багацохуровского цикла в записях XIX века // ««Джангар» и эпические традиции тюрко-монгольских народов: проблемы сохранения и исследования». Мат-лы III Между- нар. науч. конф., посв. 75-летию Калмыцкого института гуманитарных исследований РАН. Элиста: КИГИ РАН, 2016а. C. 254-256. [Ubushieva D. V. A prologue of the Baya Tsokhor cycle: $19^{\text {th }}$ century records. "«Dzhangar» $i$ epicheskie traditsii tyurkomongol'skikh narodov: problemy sokhraneniya i issledovaniya» [The Jangar and epic traditions of Turco-Mongols]. Conf. proc. Elista: Kalmyk Humanities Research Institute of RAS, 2016a. Pp. 254-256. (In Rus.)]

Убушиева $2016 б$ - Убушиева Д. В. Археографическое описание текстов песен Багацохуровского цикла XIX века // «Гуманитарная наука Юга России: международное и региональное взаимодействие». Мат-лы II Междунар. науч. конф. Элиста: КИГИ РАН, 2016б. С. 280281. [Ubushieva D. V. An archaeographic description of texts of the $19^{\text {th }}$ century Baya Tsokhor cycle texts. «Gumanitarnaya nauka Yuga Rossii: mezhdunarodnoe i regional'noe vzaimodeistvie» [Humanities in Southern Russia]. Conf. proc. Elista: Kalmyk Humanities Research Institute of RAS, 2016b. Pp. 280-281. (In Rus.)]

Чистов 1983 - Чистов К. В. Вариативность и поэтика фольклорного текста // История. Культура. Этнография и фольклор славянских народов. М.: Наука, 1983. С. 143-169. [Chistov K. V. Variability and poetics of the folklore text. Istoriya. Kul'tura. Etnografiya $i$ fol'klor slavyanskikh narodov [History, culture, ethnography and folklore of Slavic peoples]. Moscow: Nauka, 1983. Pp. 143-169. (In Rus.)] 


\title{
The Baya Tsokhor Cycle of the Jangar Epic (1857-1862): a Synoptical Analysis of Prologues
}

Bayrta B. Mandzhieval

${ }^{1}$ Ph.D. in Philology (Cand. of Philological Sc.), Leading Research Associate, Department of Mongolian Philology, Kalmyk Scientific Center of the RAS (8, I. K. Ilishkin St., Elista, 358000, Russian Federation). ORCID: 0000-0002-5644-3340. E-mail: mbbairta@yandex.ru

\begin{abstract}
Goals: The article studies prologues of the Baya Tsokhor Cycle of the Jangar Epic to reveal sustained textual patterns, determine the fundamentals and principles of formation of the representational part of the epic.

Methods: The analysis of two prologues of the Baya Tsokhor Cycle involved the use of complete synoptical comparison of texts introduced by V. Gatsak for epic compositions.

Results: The conducted synoptical comparison of prologues to the songs Duut Bogd Janyr Dogshin Khara Kinesig Dörätsülgsn Bölg (About the Victory of Jangar Bogdo over Khara Kinyas the Furious) and Dogshin Zambl Khaana Yalzu Dolan Bodngig Asr Ulan Khongor Künd Yarta Savr Khoir Dörätsülgsn Bölg (About the Victory of Ulan Khongor the Mighty and Savr the Strong over Irrepressible Warriors of Zambal Khan the Fierce) of the Baya Tsokhor Cycle resulted in 1383 line entries. The synoptical 'vertical presentation' and comparison of parity verses revealed 153 elements that coincided both textually and locally. Matches for 105 verses were discovered in some remote parts of the texts. And 112 verses differ to a certain extent but still coincide being invariants of the same source elements. As for verses to have coincided textually and locally with some fractional synonymies, those number 205. So, the synoptical comparison of the two prologues has revealed that 575 line entries are completely or partly similar, and it can be asserted that — being aware of the basic structural patterns of the epic - a jangarchi (Kalm. 'epic taleteller') would construct the narrative according to a certain reference sequence: 1) description of the country, 2) description of the construction of a palace, 3) description of Jangar, his weapons and war-horse, 4) description of the characters' whereabouts, 5) Savar's submission, 6) a feast in Jangar's palace, 7) glorification of the country.

Conclusions: The investigation of the prologues attests to the fact that repeatedly recited folklore texts basically vary. During his performances the taleteller uses ready-made topics, common parts and poetic formulas. Being an important compositional element of the epic, a prologue facilitates a deeper perception of the epic poem, heroic deeds of the main characters, emphasizes the magnitude of the events described in the country of Bumba; so, the larger the prologue, the grander epic state looks; and the prologue as such attests to that the Jangar epic had sustainably developed in a wide historical context.
\end{abstract}

Keywords: epic, tradition, prologue, manuscript, synoptic analysis, text, taleteller, variability 